Article

\title{
Climate Change Impacts and Water Management Adaptation in Two Mediterranean-Climate Watersheds: Learning from the Durance and Sacramento Rivers
}

\author{
John T. Andrew ${ }^{1, *}$ and Eric Sauquet ${ }^{2}$ \\ 1 California Department of Water Resources, 901 P Street, Sacramento, CA 95814, USA \\ 2 Irstea, UR HHLY, Hydrology-Hydraulics Research Unit, 5 rue de la Doua BP32108, \\ 69616 Villeurbanne CEDEX, France; eric.sauquet@irstea.fr \\ * Correspondence: john.andrew@water.ca.gov; Tel.: +1-916-651-9657 \\ Academic Editor: Matt Kondolf \\ Received: 19 October 2016; Accepted: 6 February 2017; Published: 16 February 2017
}

\begin{abstract}
Climate change is bringing more risk and uncertainty to water management in the world's Mediterranean-climate regions. In this paper, we compare two Mediterranean-climate watersheds: the Durance basin in southern France, and the Sacramento River in northern California, USA. For the Durance basin, we present new research on climate change impacts on water management, and discuss their implications for potential adaptation responses. For the Sacramento River, we review existing climate data and research on impacts and describe the progress in implementing various adaptation strategies. We find that the Durance and Sacramento-while certainly at different scales-nonetheless share many characteristics, such as a highly variable climate and hydrology, and extensive hydromodification and intense water competition, which will be affected by climate change. Although some issues and approaches to adaptation are unique to each region, at the same time, these two river basins are utilizing some similar strategies to cope with a changing climate, such as regional planning and management and water conservation.
\end{abstract}

Keywords: water management; Mediterranean climate; climate change; climate adaptation; Durance basin; Sacramento River

\section{Introduction}

Five years of drought in California have prompted many of the state's water managers to humbly look elsewhere for help in muddling through the dry times. Many have turned to Australia and its experience during the "Millennium Drought." Yet, though the state is frequently described as enjoying a Mediterranean climate, California seldom looks to the actual Mediterranean Basin for lessons learned about water management.

Moreover, beyond the drought this time, climate change is bringing further risk and uncertainty for water management in California and other Mediterranean-climate regions [1]. For example, climate change will likely exacerbate the "episodicity" of the hydrology in Mediterranean regions as the variability of climate increases [2]. In these regions, changes in hydrologic extremes will also change the habitat of stream biota, which may place them at more risk of extinction relative to biota living in streams in more stable climates [3]. Climate change may also favor alien species with a tolerance for changed conditions, specifically higher temperatures [1]. In an extensive review of riparian vegetation research across all five Mediterranean-climate regions (parts of California, Chile, South Africa, Australia, and of course the Mediterranean Basin itself), Stella et al. found that one of the major human impacts these regions share is climate change [4]. While climate change is hardly 
the only threat to river ecosystems-water diversions, dams, land use, and pollution being but four others-it may nonetheless exacerbate those threats [5].

In this article, we compare a major basin with a Mediterranean-style climate in northern California-the Sacramento River, the primary tributary of the San Francisco Estuary-with one that is truly Mediterranean in southeastern France-the Durance basin, a major tributary of the Rhône River. Our focus is on climate change impacts and adaptation. We first describe the setting for each basin, then examine the potential impacts of climate change, and finally discuss adaptation responses. These two basins provide for an informative comparative analysis, because not only do the Durance and the Sacramento share a similar type of climate, but also similar kinds of topography, ecology, water supply development, and flood risk. For instance, in a review of the characteristics of all five Mediterranean-climate regions, Bonada and Resh observed that California and the Mediterranean Basin were the most similar in terms of riverine ecology [1]. Where the two watersheds may differ are with respect to institutions, specific climate change impacts, and adaptation approaches.

Our analysis builds upon and joins a growing body of knowledge comparing the Sacramento River with other Mediterranean-climate river basins [1,6-9]. In this special issue, one will also find a comparison of the San Francisco Estuary (of which the Sacramento River is the main tributary) with watersheds in Portugal and Spain [10,11]. In this analysis of the Durance, the Sacramento, and climate change, we intend to continue to learn from one another, a basic tenant of adaptive management.

\section{Materials and Methods}

\subsection{The Durance Basin}

All the recent studies suggest a considerable modification of water availability in France for the future, with a clear tendency towards more severe low flows and a significant decrease in snowpack, which will lead to reduced flows in spring in mountainous areas (e.g., [12-14]). In response to these concerns, French Water Agencies have developed river-basin management plans including adaptation measures at the basin level. Partnerships have also been developed with research institutes to increase their knowledge of the impact of global change on water management. In addition, the French ministry in charge of ecology has mobilized researchers on climate change issues through several specific programs (e.g., "Management and Impacts of Climate Change" program or "Gestion et Impacts du Changement Climatique (GICC)" in French). The materials presented hereafter are new results, obtained from one of the research projects sustained by the GICC program, named $\mathrm{R}^{2} \mathrm{D}^{2}-2050$ for "Risk, Water Resources and Sustainable Development within the Durance River Basin in 2050" [15]. Through an integrated study, the $\mathrm{R}^{2} \mathrm{D}^{2}-2050$ project aimed to assess both current and future risks of water shortage in the 2050s within the Durance River basin, while taking into account changes in climate and human activities. A multi-model approach was adopted to analyze the main sources of uncertainties about the impact of global change on water management [16-18]. A set of six models with various structures including distributed physically based models (e.g., CLSM [19]) and calibrated lumped conceptual models (e.g., GR5J [20]) were applied to seven sub-basins of the Durance River basin. The $\mathrm{R}^{2} \mathrm{D}^{2}-2050$ project was the opportunity, among others, to assess the J2000 model's ability [21] to simulate flows from a large basin exposed to various climatic influences, from Alpine climate to Mediterranean climate, and to improve the CLSM model by introducing hysteresis in snow-depletion curves [19]. We have adapted three models to estimate water demand for agriculture and an econometric model to estimate water supply for domestic purposes. A model, named MORGLITE (see [14] for the early developments), was specifically developed to reproduce dam operations of the three main multi-purpose reservoirs (Serre-Ponçon, Castillon and Sainte-Croix). MORGLITE simulates water releases from the reservoirs under constraints imposed by rule curves, instream flows and water levels in summer for recreational purposes. All the models were forced by a subset of 330 regional climate projections obtained from 11 runs of four ENSEMBLES STREAM2 General Circulation Models (GCMs) [22], under the A1B scenario. The regional climate projections were produced by three statistical downscaling 
methods which are three variants of analog sorting methods (named analog, d2gen, and dsclim; see Tables 1 and 2 in [18]). In addition, six territorial socio-economic scenarios were elaborated with the help of local stakeholders during the $\mathrm{R}^{2} \mathrm{D}^{2}-2050$ project.

\subsection{The Sacramento River}

Climate change in California and specifically the Sacramento basin has been extensively examined elsewhere (e.g., [23]). Thus, for this article, we reviewed existing studies and reports on the state of the basin, potential climate change impacts, and major adaptation responses. We utilized the existing body of research described in the introduction. Beyond this research, we relied in particular on two sources of information. First, the California Water Plan Update 2013 is the State of California's strategic plan for water resources, which is updated about every five years [24]. Update 2013 is the most recent installment in this series, which began in 1957. The report is the product of an extensive technical and stakeholder process, and includes specific foci on regional planning and climate change, including an entire section on the Sacramento River Hydrologic Region. Second, the federal government (the US Bureau of Reclamation, hereinafter "Reclamation") recently published a basin study of the Sacramento and San Joaquin Rivers, with an emphasis on climate change impacts and potential adaptation strategies [25].

\section{Results}

\subsection{Common Characteristics of Mediterranean-Climate Rivers and Streams}

Mediterranean-climate regions share many characteristics, foremost among them the seasonal nature of precipitation and its often extreme variability [26]. This unique precipitation pattern in turn fundamentally influences the rivers and streams of these regions, through annual rituals of flooding and drying [26]. While the annual arrival of aridity is predictable, the intensity of drying (and then flooding) is not [26].

Civilizations have historically flourished in Mediterranean-climate regions, given their proximity to the sea and the "abundance of sunshine and mild winters," which is especially conducive for agriculture, along with healthy soils and a long growing season $[27,28]$. This welcoming environment for humans in these regions has also led to an intense competition for water between different users and needs-agricultural, municipal, industrial, the environment—resulting in tradeoffs between human demands and environmental needs [26]. Even without climate change, the competition for water in these regions will be amplified by increasing population and living standards, and global economic forces, especially those influencing agriculture.

In order to accommodate both the uncertainty of precipitation-seasonally and interannually - that brings both deluge and drought, and the demands for the water supply it provides, hydromodification is an equally defining characteristic of Mediterranean-climate regions [29]. Because of the uncertain climate yet certain competition, Mediterranean-climate rivers are highly vulnerable to human-induced environmental degradation and contain some of the most stressed riverine habitats globally [1].

\subsection{Durance River Basin}

\subsubsection{Physical Description}

Turbidus hic truncis saxisque Druentia laetum ductoris uastauit iter. Namque Alpibus ortus. (Here, tree trunks and rocks debris attest to the fury of the Durance River and its ravages in the floodplain that Hannibal crosses. This river, coming down from the Alps.) 
The Durance River basin is surrounded by the large alluvial plain of the Rhône River on the west side and by the Alps to the northeast. Its source is at an elevation of $2390 \mathrm{~m}$ in the Alps. Elevation for approximately half of its area basin is above $1000 \mathrm{~m}$ above sea level (m.a.s.l.). The major left bank tributary of the Durance River is the Verdon River (watershed area of $2294 \mathrm{~km}^{2}$ ) which is well known for its impressive canyon-20 km long and more than $300 \mathrm{~m}$ deep. The Durance River flows into the Rhône River, near Avignon. The Durance River drains an area of $14,342 \mathrm{~km}^{2}$, of which some $75 \%$ is natural forests and semi-natural areas and $22 \%$ is agricultural areas, found mostly in the lower basin.

The Durance River basin is dominated by continental rainy climate with an increasing influence of snowfalls from west to east, in parallel with the increase in elevation and of Mediterranean climate from north to south in parallel with the decrease in latitude. A northeast-southwest gradient of mean annual temperature from $-4{ }^{\circ} \mathrm{C}$ to $+13{ }^{\circ} \mathrm{C}$ is observed. The basin experiences a large range in precipitation amounts (from $500 \mathrm{~mm}$ in the downstream southern part of the basin to $3800 \mathrm{~mm}$ in the uppermost sectors). The heterogeneity in climatic influences causes high variability in terms of river flow regime. The snowmelt-fed regimes-with floods and low flows observed in spring and in winter, respectively-are observed in the mountainous part, in contrast to the southern and western part where rainfall and evaporation drive seasonal variation of runoff leading to floods in winter and low flows in summer, respectively [30]. The Durance River may experience very extreme floods as well as severe low flows, which is why the Durance River is known as a "capricious" Mediterranean river.

Water resources are under high pressure due to significant water abstractions for human uses within and out of the natural boundaries of the river basin through an extended open channel network. Water management of the Durance River basin is a long-standing issue. As from the 12th century, early concessions authorized water diversion through canals towards flour mills and farmers obtained the right to use water for crops during fixed periods of the year. During the 16th century, many hydraulic infrastructures were constructed to transfer water of the Durance River beyond the limits of the catchment to southern areas for irrigation purposes, and later for domestic water supply of large cities (e.g., Marseille). At the end of the 19th century, a series of hydroelectric power stations were built to serve urban areas and industrial companies. Later, several conflicts between water uses occurred as a consequence of a sequence of severe droughts, demonstrating that local water resources' availability could no longer meet water demands. To manage the growing opposing interests, the Act of 11 July 1907 created the Executive Committee of the Durance ("Commission Exécutive de la Durance" in French) in charge of defining rules for rational water allocation and for withdrawal restrictions in certain low-flow situations. The Planning Act of Serre-Ponçon and the Lower Durance ("Loi d'aménagement de Serre-Ponçon et de la Basse Durance" in French) of 5 January 1955, marked the beginning of the development of the Durance and Verdon Valleys, including both the Durance River and the Verdon River. The project had the three following objectives: (1) production of renewable energy; (2) supply of water for cropland irrigation and (3) supply of drinking water to southeastern France and reduction of flood damage. The Serre-Ponçon Reservoir is the largest impoundment in metropolitan France and the second largest reservoir in Europe in terms of storage capacity $\left(1.2\right.$ billion $\left.\mathrm{m}^{3}\right)$. The Castillon and Sainte-Croix Dams located along the Verdon River are the two other keystones of the development project.

Dams and canals of the Durance and Verdon Valley have considerably modified the river flow regime. The Durance River is certainly one of the most regulated rivers in France. Natural and observed annual hydrographs are displayed in Figure 1. Time series of daily river flows were obtained from observed discharges in the main streambed of the river, records of reservoir level variations, declared water abstractions and overflows for all dams located in the headwaters. The natural river flow regime here is predominantly affected by snowmelt processes with high flows in spring and low flows in winter and summer. The peak due to snow melting is missing in the observed hydrographs of the Durance River at Serre-Ponçon, as a result of dam operations. That is, during spring and early summer, reservoirs store inflows naturally produced by snowmelt; in winter, reservoirs give water back to meet high peak demands for energy and, in summer, stored water is released to meet multipurpose 
needs such as irrigation and domestic water in compliance with requirements on instream flows and on minimum reservoir water level for recreational uses in summer. At the three other locations, the gauging stations measure the imposed instream flow most of the time and departures to the instream flow are caused by flood occurrence. However, short available record lengths induce high day-to-day variability observed for the median hydrographs.

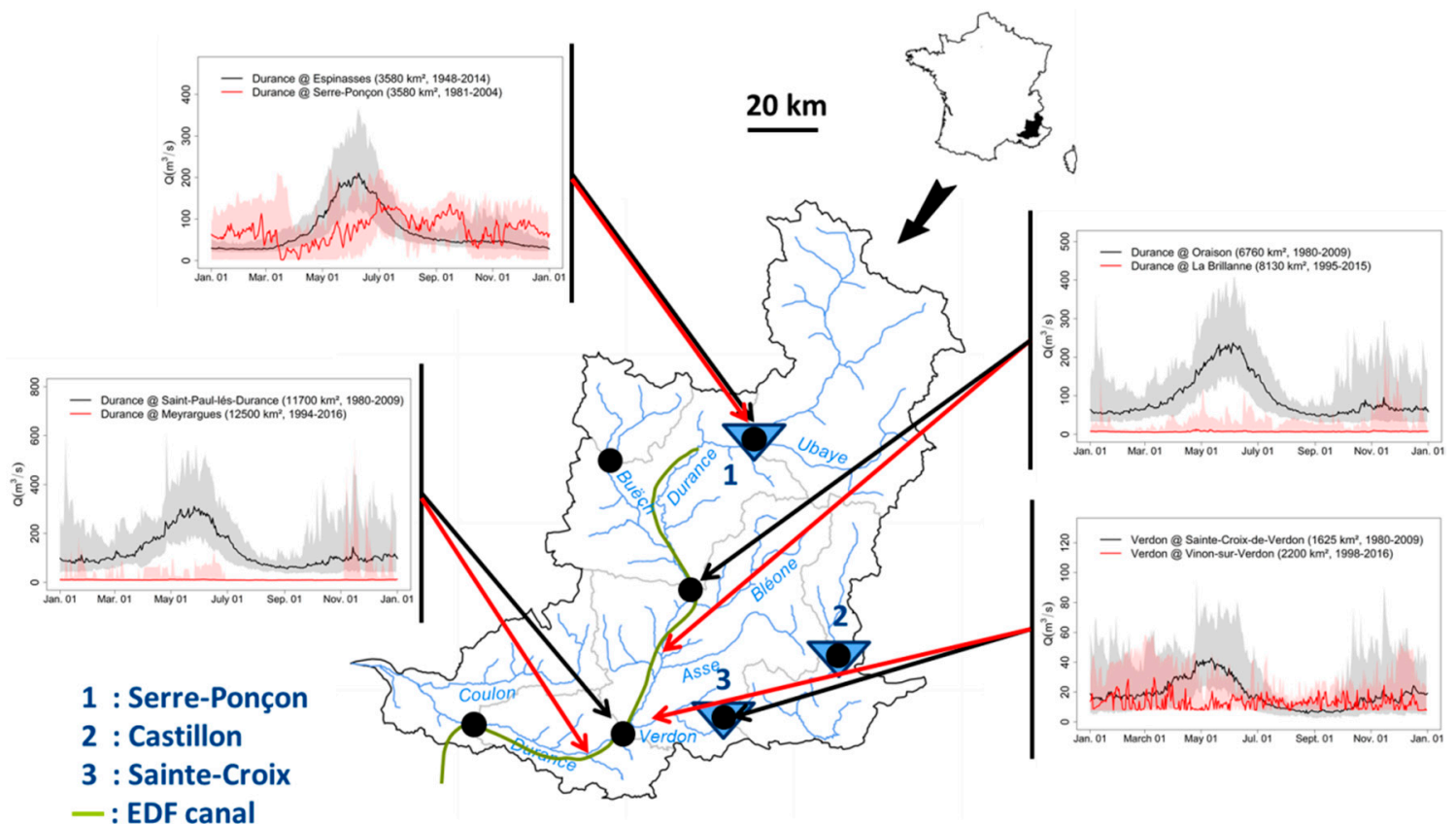

Figure 1. Comparison of natural (black) and observed (red) median annual hydrographs at different locations within the Durance River basin. Shading indicates the interdecile range of the daily river flow. Triangles indicate the location of the main reservoirs. Black dots are the locations of the sub-basins examined within the "Risk, Water Resources and Sustainable Development within the Durance River Basin in 2050" ( $\left.\mathrm{R}^{2} \mathrm{D}^{2}-2050\right)$ project.

\subsubsection{Water Infrastructure}

The Canal Saint-Julien ( $200 \mathrm{~km}$ long) was the first canal, built in the 12th century, for irrigating agricultural plains located near the lower Rhône River out of the boundary of the Durance River basin. The canal system grew progressively between the 16th and the 19th centuries. Among them, the Craponne Canal has contributed to the development of irrigated croplands in the Crau Plain; the Marseille canal was built in the 19th century to supply the city of Marseille with domestic water. At the present time, the lower Durance contains a dense network of canals $(\sim 500 \mathrm{~km}$ long $)$ serving local demand for drinking, agricultural and industrial water.

A total of 17 dams and 30 hydroelectric plants operate in the Durance and Verdon Valleys. Most of the hydroelectric plants generate water along the Électricité de France (EDF) canal (250 km long), which diverts a large portion of the outflows from the Serre-Ponçon Reservoir from the natural riverbed. One part of diverted water runs southwest and supplies fresh water to the Berre Pond, which is naturally connected to the Mediterranean Sea. The other part returns to the natural mainstem of the Durance River downstream. The Durance and Verdon Valleys generate, on average, 6.5 billion $\mathrm{kWh}$ per year. The energy production corresponds to the yearly consumption of a city of 2.5 million people. One of the particularities of the French electricity production system is that the baseline production (approximately 80\%) is supplied by nuclear power plants, and hydropower provides supplements to ensure matching between supply and demand for peak demands (e.g., for heating during cold weather conditions in winter). The 30 hydroelectric plants are able to meet a peak demand of $2000 \mathrm{MW}$ in less 
than $10 \mathrm{~m}$. The three main multipurpose reservoirs with a total storage capacity of 2.3 billion $\mathrm{m}^{3}$, beyond electricity production, secure water supply across the Provence-Alpes-Cote-d'Azur during drought events and may partly provide flood protection and control. A total of $200 \mathrm{Mm}^{3}$ of the water stored in the Serre-Ponçon Reservoir is specifically saved for irrigation needs between 1 July and 30 September each year, as the Ministry of Agriculture financed a part of its construction.

\subsubsection{Water Management and Regulatory Framework}

The Durance and Verdon Valley is a vast and complex system (Figure 2). Operating water management rules are therefore complex and inherit both from the national regulatory framework and the historical water rights existing across the areas.

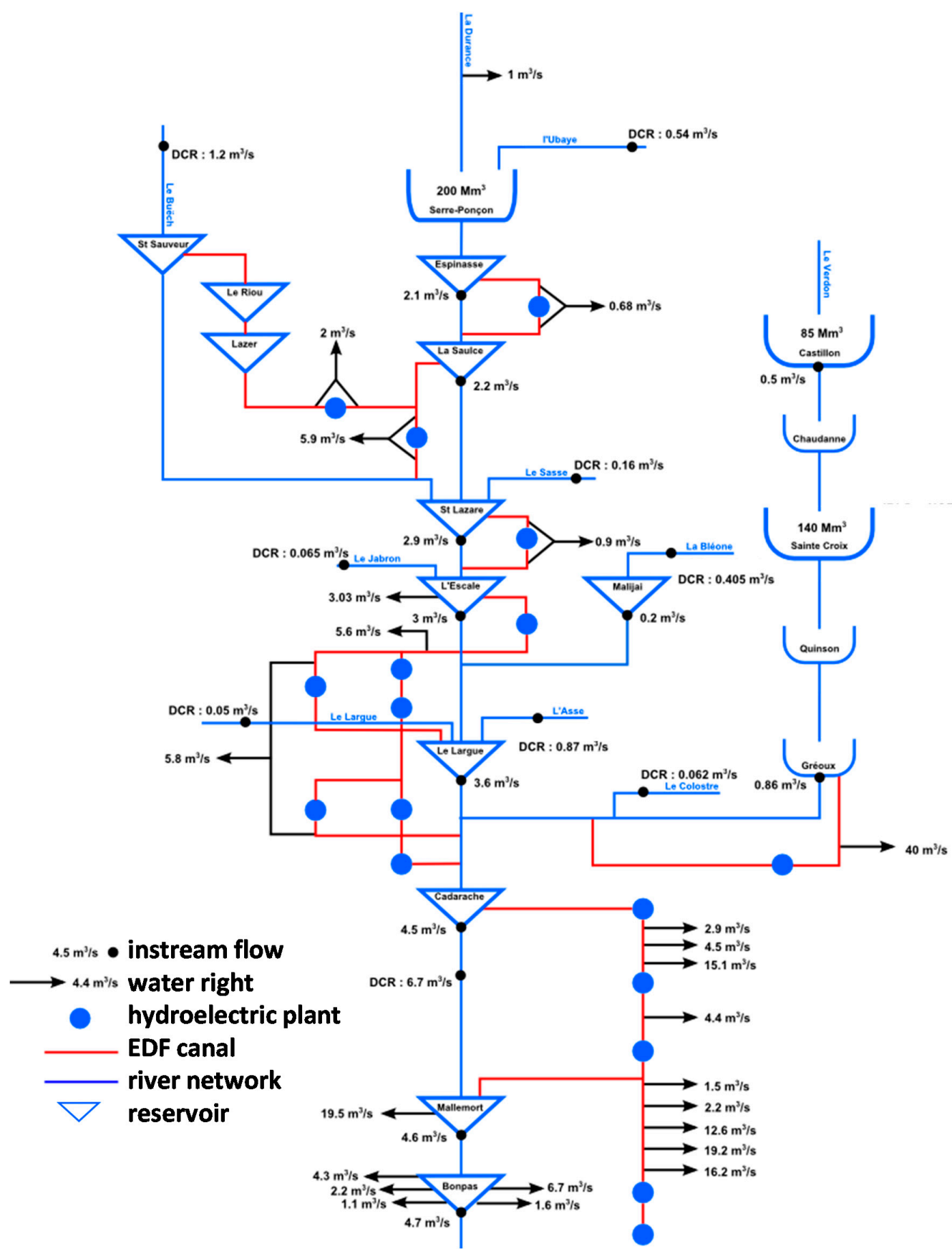

Figure 2. Simplified representation of the Durance and Verdon Valleys (data source: EDF, Actéon). 
The Fishing Act of 29 June 1984 lays the basis for balanced water management with the objectives to conciliate conflicts in water use in addition to environmental protection. The instream flows downstream to all the reservoirs that were present in the year 1984 are fixed to a flow threshold higher than $1 / 40$ th of the mean of the annual natural discharge $\overline{Q A}$ estimated at its location. The values $\overline{Q A} / 40$ were finally retained for the three dams of the Durance and Verdon Valley, since they were built before 1984 .

The Fishing Act was followed later by the French Water Act of 3 January 1992. Article 9 recommends implementing adapted measures temporarily restricting or suspending water uses to mitigate the risk or the effect of one severe low flow event. A permanent monitoring scheme regarding surface water has been established using real-time observations of discharge at gauged stations [31]. The severity level of a current low-flow event and the requirement for mitigation actions result from the comparison of observations to four fixed thresholds. The DCR level ("Débit de Crise") is the most critical threshold under which the supply of drinking water to the population and the preservation of aquatic ecosystems are jeopardized, and highly restrictive measures for non-priority uses are adopted to limit water abstraction until observed discharge exceeds the DCR level.

\subsubsection{Climate Change Impacts}

\section{i. Precipitation and Temperature}

Not unexpectedly, regional climate projections suggest an increase in air temperature across the Durance River basin. The Durance River basin will probably experience a warmer climate by the 2050s. Changes with respect to the 1980-2009 period are spatially uniform (on average $+1.6^{\circ} \mathrm{C}$ ). Changes are more pronounced in summer $\left(\sim+2.1^{\circ} \mathrm{C}\right)$ than in winter $\left(\sim+1.3^{\circ} \mathrm{C}\right)$. On the other hand, the regional climate projections suggest that potential changes in future precipitation are more uncertain There is general agreement that the PET estimated by the Penman-Monteith formulation will have increased by the 2050 s $(\sim+55 \mathrm{~mm} /$ year). Changes in air temperature impact substantially snow processes in the mountainous areas, with a probable decrease in snowfall, a trend towards reduced winter snow storage and a shift to earlier snow melting.

ii. Hydrology

Figure 3 shows the projected relative changes in the five-day average flows by the 2050s with respect to the 1980-2009 period. A measure of the current variability in the river flow regimes is given by the interquartile of anomalies to the mean five-day average flows. Statistics are computed over the 330 hydrological projections obtained from the set of 330 regional climate projections. Results are provided for five hydrological models for three basins of importance: daily discharges of the Durance River at Serre-Ponçon and of the Verdon River at Sainte-Croix are the total natural inflows to the dams, and the Durance River at Saint-Paul-lès-Durance is representative of the possible alterations of the natural river flow regime, integrated over the catchment.

Using the average of the 330 climate projections, the Durance River basin will experience a warmer climate by the 2050s and all the models predict a significant decline in mean annual renewable water resources with an accompanying decrease in summer flow (Figure 3). However, dispersion within hydrological models is perceptible on the graphs, e.g., the CLSM model projects more substantial decrease in summer flows than the other models. This scattering stems from the difference in the evapotranspiration and snow pack components of the selected hydrological models [18]. The sign and the magnitude of the seasonal changes depend on the current river flow regime. Although the models produced different temporal patterns and magnitudes of change, a consistent substantial increase in flows is identified from late winter to mid-spring for basins in the mountainous areas (e.g., more than $+20 \%$ for the Durance River at Serre-Ponçon). Thus, the headwaters may experience a decrease in snowpack, leading to reduced flows in the spring season and to an earlier timing of snowmelt, as a consequence of the increase in mean air temperature. The tributaries less affected by 
snow melt processes may face the most significant changes in summer (e.g., around $-20 \%$ for the Verdon River at Sainte-Croix-de-Verdon). Mean changes obtained for the five hydrological models are values close to the first quartiles observed under current conditions. This result indicates that low flow events more severe than those observed in a recent past could be expected. In addition, results show a rise of both the low-flow severity and the low-flow duration and a decrease in water resources in summer, which corresponds to the peak water demand for irrigation. No significant change in flood severity was found.

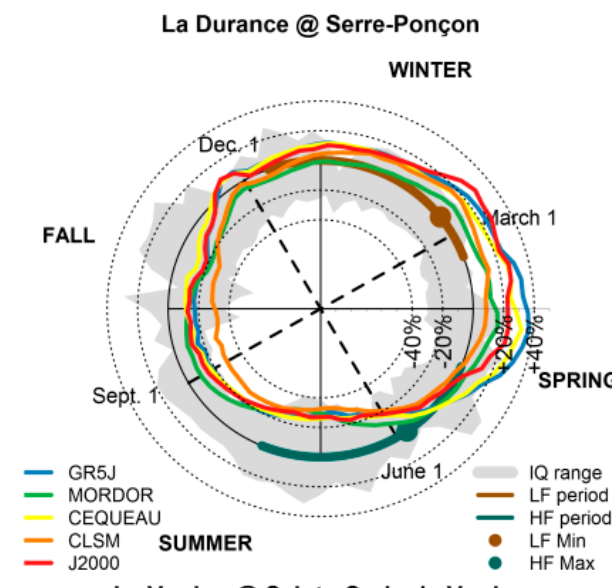

Le Verdon @ Sainte-Croix-de-Verdon

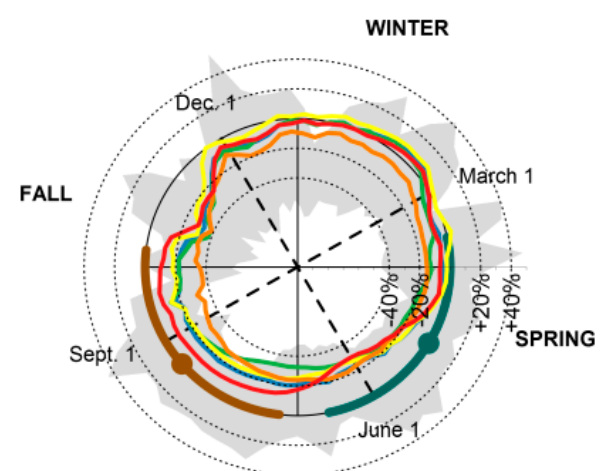

SUMMER

La Durance @ Saint-Paul-lès-Durance

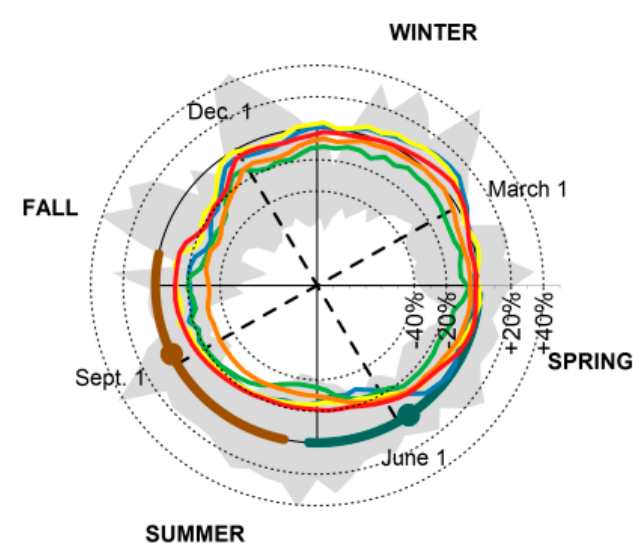

Figure 3. Mean relative changes of five-day moving average discharges for the five hydrological models GR5J, MORDOR, CEQUEAU, CLSM and J2000 with respect to the 1980-2009 period. Thick lines represent the present-day, three-month period of low flows and high flows. The dots indicate the occurrence of the minimum and the maximum of the mean of the five-day moving average discharges under current conditions. 


\section{iii. Biodiversity}

Changes in aquatic ecosystems were investigated within the $R^{2} D^{2}-2050$ project on the Asse River. This tributary of the Durance River regularly experiencing dry conditions was chosen as a representative of intermittent streams frequently observed under a Mediterranean climate. An original approach was developed to simulate flows and biodiversity richness at poorly gauged sites [32]. Two hydrological models with distinct structures were first used to simulate daily flows, and a post-processing technique derived from the quantile mapping approach (e.g., [33]) was carried out to allow the streams to completely dry. Flow intermittence $\sim$ biodiversity relationships calibrated under present-day conditions [34] were finally applied to predict future community richness. Results show that approximately two taxa could be lost from invertebrate communities due to increase in both occurrence and duration of zero-flow events by the 2050s. However, there are obvious limitations to this study, e.g., the opportunity for invasive species to take advantage of the more frequent zero-flow conditions or the adaptive capacity of keystone species was not considered here. Therefore, the conclusions should be refined to identify which species would most likely vanish from river communities, and such modelling exercises need to be applied to other river basins, especially in those with different spatio-temporal patterns and magnitudes in flow intermittence than the Asse River.

\subsubsection{Territorial Foresight and Its Impact on Water Management}

Forward-looking activities were conducted in parallel with the development of water management models [35]. The results are six socio-economic narrative scenarios (Table 1) elaborated with the involvement of local experts, including researchers and stakeholders (e.g., representatives of water supply companies, industries, natural parks, irrigator associations, electricity producers, state services). One of the scenarios is the "Trend-based" scenario, which assumes the continuation of the observed recent trends in the drivers of water demand at a regional scale. Another scenario is the "Business-as-usual" scenario, which assumes that no major change in water demand behavior occurs. The "Business-as-usual" scenario, based on the conditions observed in 2010, allows assessing the impact of climate change regardless of any other anthropogenic changes. The four last socio-economic scenarios, each with a specific "color," have been suggested by stakeholders. For example, in the "Investment" scenario, the world by 2050s is one where energy is cheap; this ensures sustained and strong economic growth. The Durance River basin and its neighboring areas strive for a maximum development. Local economic interests on industrial and tourism activities will overshadow both environmental issues and agricultural activities. The renewal of the industrial sector will induce an increase in energy demand, which will be mostly provided by hydroelectric plants of the Durance and Verdon Valley. New tourism activities (e.g., vast amusement parks, ski resorts well-equipped with snow cannons, etc.) will appeal to a growing seasonal population. The local economic drive will attract a rising population and new inhabitants will live preferentially along the southern coast. In the absence of land management, a large part of the current irrigable lands will be urbanized.

The six socio-economic scenarios were translated into quantitative changes in the parameters of the developed water use models valid for the 2050s and their related water demand at a regional scale; even neighboring areas of the Durance River basin were computed considering a subsample of ten representative regional climate projections taken from the 330 downscaled climate projections through a Latin Hypercube Sampling [36]. Results show a decrease in total water abstraction (TWA) for all but one scenario (Figure 4) - the business-as-usual scenario-which leads to TWA close to the ones obtained under past conditions. The average change over the five socio-economic scenarios and the ten representative climate projections for the future is around $-400 \mathrm{Mm}^{3} /$ year, with respect to the baseline period 1980-2009.

The fractions of TWA required for each water use varies moderately with the socio-economic scenarios. However, the losses from the conveyance and distribution systems transporting the water from point of withdrawal to point of use is by far the most water consuming usage for all the scenarios 
(between $38 \%$ and $55 \%$ of TWA). The ratios to the TWA are around $30 \%$ and $18 \%$ of TWA for agriculture and domestic needs, respectively.

Table 1. Sign of the change in the drivers of water demand with respect to 2010, considered in the six socio-economic scenarios.

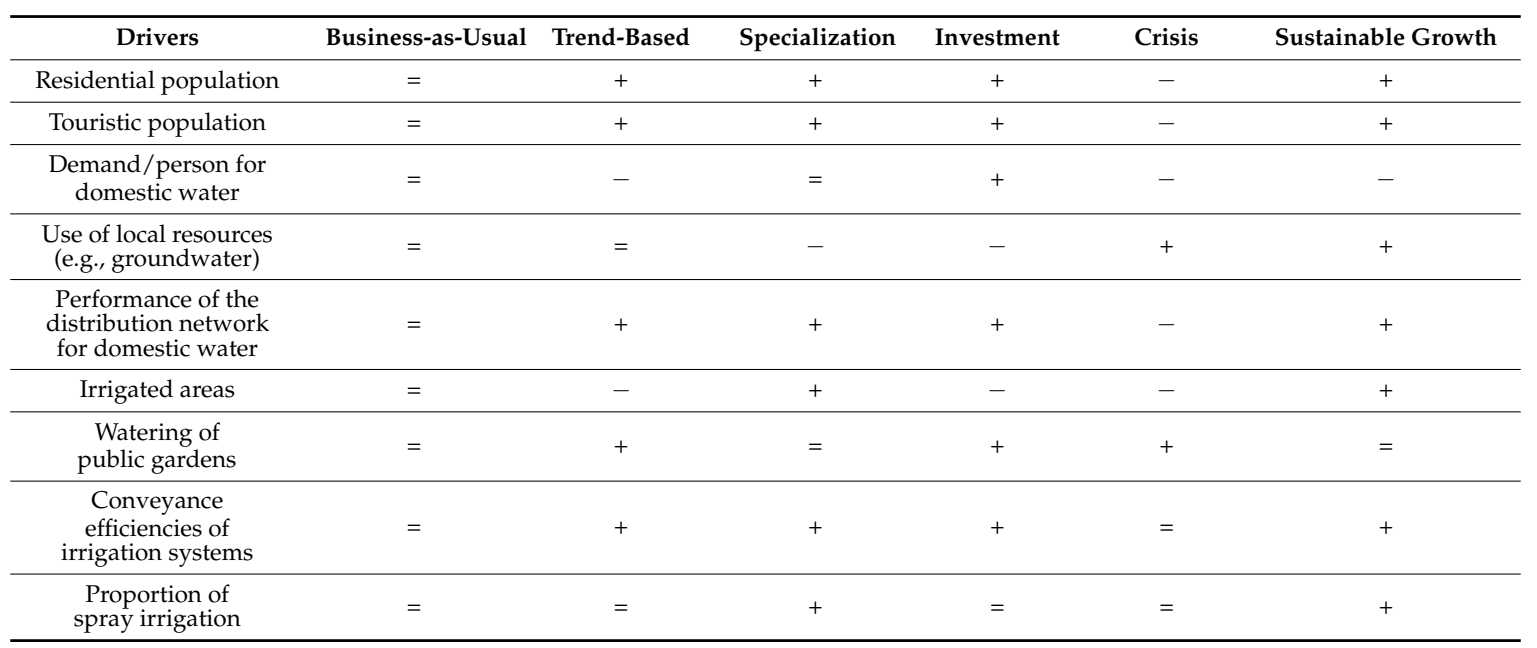

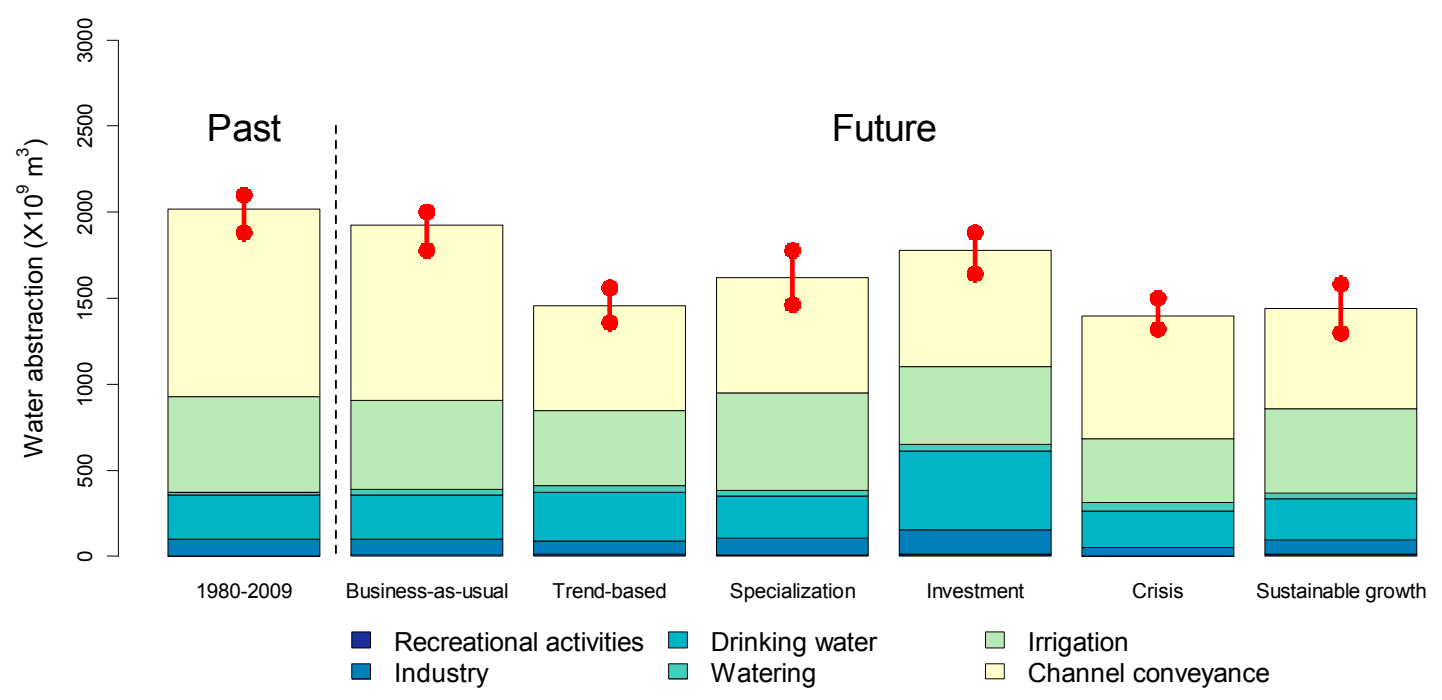

Figure 4. Mean total volume of water abstraction over the ten representative regional climate projections. Red dots indicate the minimum and the maximum values. The period "1980-2009" refers to results obtained with the baseline climate 1980-2009 simulated by the General Circulation Models (GCMs) and with the parameters of the water use models calibrated against observations over the period 1980-2009.

For a given socio-economic scenario, values for TWA derived from the ten regional climate projections differ only marginally. This finding highlights here the higher dependence of TWA to the assumptions of the socio-economic scenarios than to the future climate conditions. The small sensitivity of TWA to climate conditions can be explained by the structure and the settings of the water use models. Drinking water needs are simulated through a multivariate econometric approach and no climate descriptor has been included in the model as an explanatory variable. Changes in domestic water are driven by the population supplied by the Durance and Verdon Valleys. Water losses due to the irrigation systems are related to agricultural needs and balanced by the conveyance efficiency, which is the most influencing factor of change. Irrigation is finally the only usage that is 
explicitly affected by climate evolution and therefore is the main source of uncertainty induced by climate change.

The decrease in TWA is here mainly due to the implementation of water conservation measures in all of the scenarios. Conveyance efficiencies for the irrigation systems are supposed to remain constant ("Crisis" scenario) or to improved. This assumption is consistent with one of the stated priorities of the French water agencies-i.e., to tackle water wastage and to achieve significant water savings-and has not been objectively called into question by stakeholders during the participatory approach.

Despite the decrease in total water abstraction, pressure on water resources is intensified: the magnitude of the change in mean annual discharges $\left(\sim-20.5 \mathrm{~m}^{3} / \mathrm{s}=-650 \mathrm{Mm}^{3} /\right.$ year for the Durance River basin at Saint-Paul-lès-Durance) is higher than the intensity of the change in water abstraction ( $\sim 400 \mathrm{Mm}^{3}$ /year) with respect to the baseline period 1980-2009. The standardized net inflow $m$ introduced by Hazen [37] was adapted to provide a rough measure of the resilience of the Durance River basin considered as a global reservoir [38] and is given by:

$$
m=(1-T W A / \overline{Q A}) / C v=(\overline{Q A}-T W A) / \sigma_{Q A}
$$

where $\overline{Q A}, \sigma_{Q A}$ and $C v$ are the mean, the standard deviation and the coefficient of variation of the annual natural discharge $Q A$ at Saint-Paul-lès-Durance, respectively. The Durance River basin, considered as a system, is projected to be less resilient than under current conditions. The index $m$ is projected to be lower by the 2050s with respect to the baseline period 1980-2009 and remains above 1 . The risk of water shortage is higher in the future than under present conditions but remains unlikely. The difference between current and future year-to-year variability in annual water resources is small and the change in $m$ is mainly explained by the changes in the unconsumed water $(\overline{Q A}-T W A)$.

The MORGLITE model was used to simulate the impact of the changes in the natural water cycle and the water use on reservoir operation of the three main dams (Serre-Ponçon, Castillon and Sainte-Croix) on present-day conditions. A hierarchy of water use was set in the MORGLITE models (priority to the respect of the environmental flows in summer along the Durance and Verdon Valley). The most critical situation is finally obtained with the "Business-as-usual" scenario and so, the volume of $200 \mathrm{Mm}^{3}$ stored in the Serre-Ponçon reservoir for agriculture is not sufficient to meet the total irrigation needs every year by the 2050s. However, for the other five socio-economic scenarios, results suggest a full compliance with water needs downstream of the reservoirs but a lower flexibility for hydropower management during peak energy demand and a decrease in the energy produced as a consequence of reduced annual inflows. However, the sensitivity to the changes differs from the Serre-Ponçon Reservoir (Durance) to the Sainte-Croix and Castillon Reservoirs (Verdon) as a consequence of different types of water uses. For the Serre-Ponçon Reservoir, the water savings incentive programs included in five of the six socio-economic scenarios alleviate the negative impact of climate change on irrigation needs. For the two other reservoirs located in the Verdon River basin, the increase in abstraction for domestic uses will make the water levels for recreational purposes in summer difficult to fully respect. By the 2050s, with present-day conditions, release should be controlled to minimize seasonal variations in storage in order to limit the risk of water shortages.

In sub-basins not connected to the Durance and Verdon Valley, such as the Buëch River basin, the probability of restrictions will be higher by the 2050s due to more frequent occurrence of discharge under the DCR level.

\subsubsection{Adaptation Strategies}

Adaption strategies to climate change are developing in France along with recent initiatives taken at different scales (from national to local). In 2011, France adopted a general framework for action-the French National Climate Change Impact Adaptation Plan ("Plan National d'Adaptation au Changement Climatique (PNACC)" in French)—with numerous recommendations related to research and observation. Five priorities of the first PNACC related to water resources are highlighted: 
(i) to increase knowledge on climate change impacts; (ii) to develop specific tools for monitoring water resources and water allocation from the medium to long-term perspective; (iii) to encourage water savings and to ensure more efficient water use; $(i v)$ to foster development in accordance with local available water resources; and $(v)$ to account for adaptation measures in water management planning. The ambition is to reach a $20 \%$ decrease in water abstraction by the 2020 s. The PNACC is currently being reviewed.

Following recommendation (v), adaptation strategies fall now within the scope of the River Basin Management Plans or RBMP ("Schéma Directeur d'Aménagement et de Gestion des Eaux" in French). The RBMPs, established every five years since 1992 in cooperation with local stakeholders, outline the main strategic orientations of the French Water Agencies. The objectives are defined in compliance with both the French regulatory framework and European directives, notably the Water Framework Directive.

The Durance River basin, like all the tributaries of the Rhône River basin, is located within the hydrographic district of the Rhone-Mediterranean and Corsica (RMC) Water Agency, which has promoted the emergence of adaptation issues through different tools:

i. A synthesis on the current state-of-knowledge on the scientific research related to the impact of climate change;

ii. An analysis of the vulnerability in different water-related sectors (water resources, soil-moisture levels, biodiversity, nutrient water quality) within the hydrographic district to climate change;

iii. A program of actions, which provides necessary means (including financial aid) for local decision makers to limit soil sealing, to reduce water waste, to preserve or recover expanding flood areas and wetlands.

These tools combine actions to increase public awareness (i, ii) and concrete measures to underpin system resilience facing global change (iii). They are part of the plan for adaptation to climate change of the RMC Water Agency [39], an unprecedented major initiative launched in France in 2014 that provides guidance for the next RBMP (2016-2021).

A first example of concrete measures is the "win-win" agreements signed between the Canaux de Vaucluse and the French electricity producer EDF in charge of the Durance and Verdon Valley. Financial supports from EDF and from the RMC Water Agency encourage reduction in water use for irrigation. An attractive annual compensation is provided to farmers to reach targeted annual objectives and to go beyond. Achieved water savings are not only dedicated to generate energy; they contribute to keep necessary margins to meet the water demands for the different users. The former agreement was successful since it leads to a decrease in water demand from $310 \mathrm{Mm}^{3}$ in 1997 to $220 \mathrm{Mm}^{3}$ in 2012. The agreement has been renewed in 2014.

A second example is given by the agreement contracts for the Canal de Manosque ( $57 \mathrm{~km}$-long main canal with a secondary network of smaller canals of $175 \mathrm{~km}$ long). One of the key objectives of the contracts is the implementation of water savings through two main orientations: the transition from surface to pressure irrigation systems and the implementation of the regulation on the canals. The agreement initially valid for the period 2008-2014 has been extended until 2017 by an amendment to achieve all the works originally scheduled. The total investment cost is valued at $€ 13.7$ million with financial support of $€ 4.7$ million from the RMC Water Agency. Expected volumes of saved water are estimated at $6.8 \mathrm{Mm}^{3}$, with the commitment of at least $50 \%$ of the saved water to be released to the natural environment. Currently, as an experiment, saved water flows into the Largue River. A hydroelectric power plant is planned between the canal and the Largue River to financially support the local investments. Other agreement contracts do exist in the Vaucluse with the same objective ( $50 \%$ of saved water dedicated to the natural environment).

The $\mathrm{R}^{2} \mathrm{D}^{2}-2050$ project has also provided an objective support for the emergence of a collective strategy of water management, through the communication of the major results and the uncertainties related to the future. A workshop organized with stakeholders at the end of the project has pointed out 
the possible actions for adaptation. Stakeholders have stated that, globally, the full compliance with water needs for priority uses downstream from the reservoir leads to less flexibility for hydropower management during winter peak energy demand if current water management rules are unchanged; uncertainties do exist, but a consistent reliable trend towards more severe droughts is highly probable. Different actions were suggested by the audience:

- To change the current arbitrage of the rules for water allocation and priorities given to water uses,

- To discuss the methods carried out to prioritize water uses before making decisions,

- To search for local water resources,

- To create an institution in charge of monitoring water resources availability and water demands at the scale of the Durance and Verdon Valley.

\subsection{Sacramento River Basin}

\subsubsection{Physical Description}

Originating near the California-Oregon border, the Sacramento River emerges from volcanic plateaus and forested mountains and runs over $700 \mathrm{~km}$ south-southeast on its way to the sea [7]. For most of its journey, the river travels between the Klamath and Coast Mountain Ranges on the west, with the Cascade and Sierra Nevada Mountain Ranges to the east, historically nurturing a great valley in between and its soils and riparian forests. At the city of Sacramento (the California state capitol, named for the river), it splits into two channels-a mainstem and a deepwater ship canal-as it enters the Sacramento-San Joaquin delta, a vast, inland reclaimed marsh now mostly composed of islands and sloughs, reminiscent of parts of the Camargue, the delta of the Rhône River. At Suisun Bay, the river ends at its $1.6 \mathrm{~km}$-wide confluence with the San Joaquin River, just upstream of San Francisco Bay, for which the Sacramento is the main sediment source [40]. The lower reaches of the river are tidally influenced and brackish from the Pacific Ocean.

The river and its 12 major tributaries compose the largest watershed in California, draining much of northern California, over $70,000 \mathrm{~km}^{2}$, or $17 \%$ of the state (Figure 5) [23]. It is also arguably the most important basin in the state, providing water supply that is exported throughout California for many of its cities and some of the most productive farmland in the world; average annual runoff from 2001 to 2010 was $28 \mathrm{~km}^{3}$, representing one-third of California's total surface water supply [23]. Land use is primarily rural in the catchment, though almost three million people live there, mostly concentrated in metropolitan Sacramento; in 2050, 4.5 million people may reside in the region [23]. Ecosystems evolve with elevation, with mixed conifer species in the mountains, grasslands and woodlands (primarily oaks) in the foothills, and irrigated farmlands (nearly 800,000 hectares) and some wetlands and riparian habitat on the valley floor $[23,41]$. The region serves as important wintering habitat for migratory birds on the Pacific Flyway [23].

As it turns out, the first foreigners to observe the Sacramento River were from the Mediterranean, and they may have felt right at home in the natural environment of California [42]. From snow-capped mountain top to sea level, the basin experiences a diverse climate, including Mediterranean, with large seasonal and inter-annual variability in precipitation, which in turns results in highly variable runoff patterns. From 1981 to 2010, the average annual precipitation was $96 \mathrm{~cm}$, primarily from just several or even a few major Pacific storms colliding with the Sierra Nevadas each year [23]. Despite the arithmetic ability to arrive at an average, the region is in reality a land of extremes, swinging regularly from flood to drought and back again; for instance, the Great Floods of 1861-1862 — which turned the lower Sacramento basin into an inland sea-were promptly followed by the Great Drought of 1862 [43]. In 1808, Lieutenant Gabriel Moraga of the Spanish Empire named the river El Rio de los Sacramentos-the River of the Sacraments [42].

With the Gold Rush-born in a tributary of the Sacramento River-later in the 19th century, humans greatly accelerated the extensive modification of the watershed. For example, the earliest major impact to the catchment was intensive sedimentation due to hydraulic mining for the precious 
metal. In fact, the amount of sediment in suspension in some of the tributaries of the Sacramento River in the "hydraulicking" era drew formal comparisons to the Durance basin, "the famously muddy river of southern France" [44].

Figure SR-2: Sacramento River Hydrologic Region Watersheds

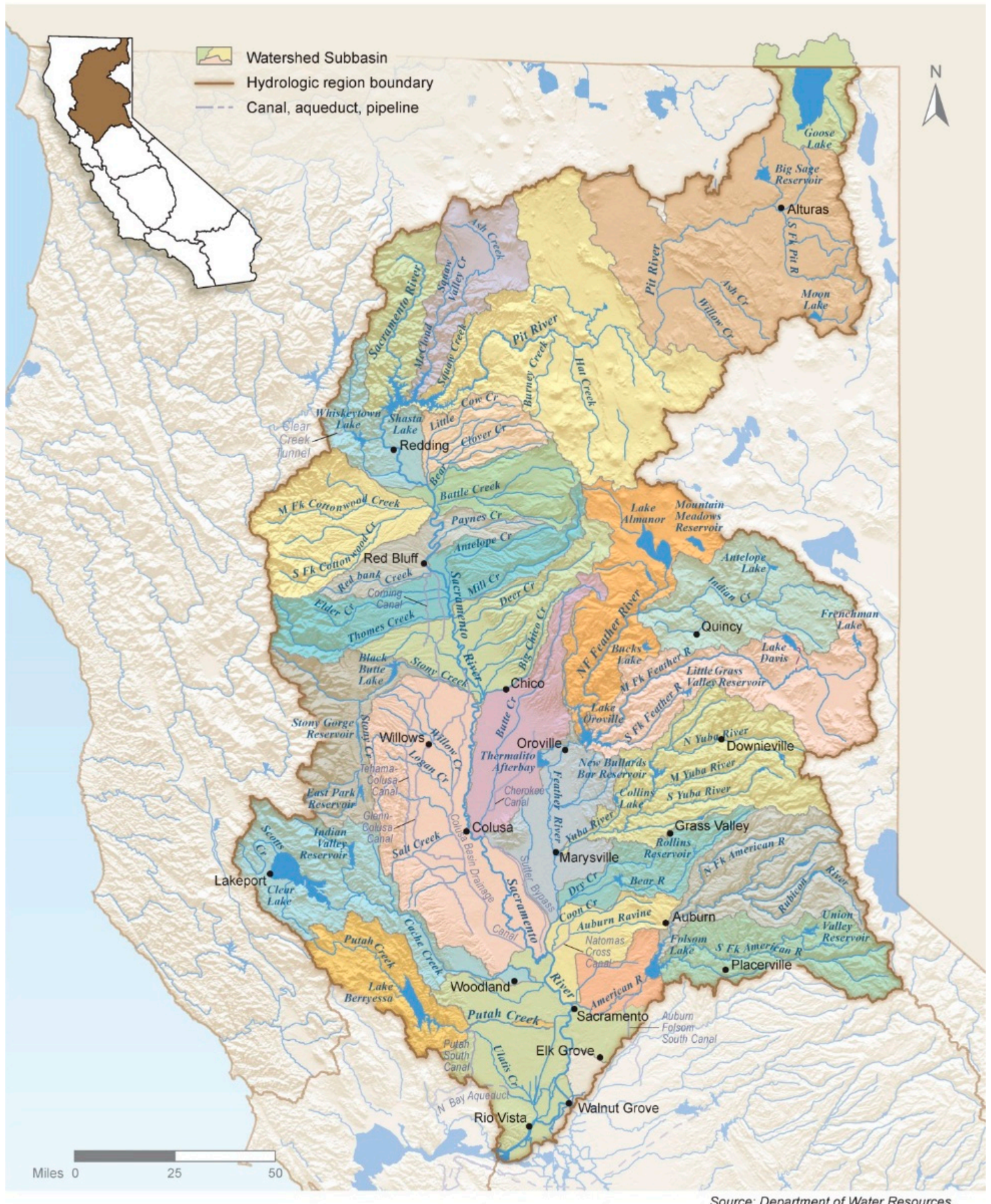

Figure 5. The Sacramento River watershed encompasses much of northern California, eventually flowing into the San Francisco Estuary (from the California Water Plan Update 2013, California Department of Water Resources [23]). 
The inconvenience-for humans—of the naturally variable flow is the "main motivation for, and casualty of," the dam building era in California [28]. Like other Mediterranean-climate regions, California has constructed both infrastructure and institutions to cope with the uncertainty of water availability on a scale markedly greater than in humid climates elsewhere in the US $[27,28]$. The Sacramento River and its tributaries include some of the largest dams in California, including Shasta Dam which tamed the river's mainstem and impounds the largest reservoir in California $\left(5.5 \mathrm{~km}^{3}\right)$. The statewide mismatch of supply and demand-temporally and spatially-as well as the need for salinity control in the delta and flood protection on the valley floor, has collectively led to a total reservoir capacity of $19 \mathrm{~km}^{3}$ in the basin, the largest of any region in California [23].

Extensive hydromodification of the Sacramento basin has resulted in extensive modification of ecology and geomorphology. For instance, due to impoundments and diversions, flood peaks are smaller and less frequent, and summer baseflows higher and colder than natural conditions, resulting in a "flattening of the hydrograph" that has reduced habitat and its complexity [28]. Beyond flow alteration, dam construction has also fragmented riparian systems; blocked fish passage; abridged and degraded floodplain habitat; modified water temperatures; and impaired sediment and nutrient transport [23,27].

Unusual for Mediterranean-climate rivers, the Sacramento River is home all year to anadromous salmonids, including the four most southern runs of Pacific (Chinook) salmon (Oncorhynchus tshawytscha), and the Central Valley steelhead trout (O. mykiss) [2]. Currently, the endangered winter-run Chinook is the salmon species nearest extinction, which used to spawn in the upper elevations of the Sacramento River system, now severed by Shasta Dam-and instead now paradoxically spawn in the cold waters discharged by the very same dam, through its temperature control facilities [2,45]. In a changing climate, spring-run Chinook-whose spawning habitat is currently limited to just three tributaries of the Sacramento River-may also be especially susceptible, because the streams in which they spend the summer (before spawning in the fall) will experience both lower flows and higher temperatures [46]. Already teetering on the brink of extinction, the year-round resident delta smelt (Hypomesus transpacificus), which regularly makes its home in the lower reaches of the Sacramento, may be further vulnerable due to increasing water temperatures and salinity intrusion from the Pacific.

Applied water use in the Sacramento River Hydrologic Region averaged $11 \mathrm{~km}^{3}$ annually from 2005 to 2010, mostly for agriculture [23]. During that same time period, groundwater played an important role, providing an annual average of $3.3 \mathrm{~km}^{3}$ of water, representing $31 \%$ of total water supply, also mainly for farms, though it also met half of urban water demand [23]. Besides water supply, the Sacramento River supports multiple beneficial uses, including hydropower (nearly $5000 \mathrm{MW}$ of capacity), recreation, and navigation; large vessels from the Pacific can venture $150 \mathrm{~km}$ inland to the deepwater port at West Sacramento. In terms of water quality, surface waters in the watershed remain impaired by contaminants from the legacy of mining, including copper, cadmium, zinc, and mercury [23]. Agricultural runoff and urban stormwater are sources of pyrethroids and organophosphate pesticides [23].

\subsubsection{Institutions}

Water governance in the Sacramento River basin-much like in the rest of California-is highly decentralized. As Sacramento native Joan Didion once observed of California, "distrust of centralized government has historically passed for an ethic" which is reflected in the numerous local governments involved with water management [47]. For example, the region has over 500 community drinking water systems, and nearly another 500 local agencies with flood management responsibilities, some of which originated in response to Gold Rush-era hydraulic mining [23,48]. As Serro-Llobet et al. note in this issue, many if not most water agencies have "narrowly defined and sometimes conflicting missions," and generally lack coordination [11]. Further, ad hoc approaches to water management are 
driven by individual legal mandates and projects that often focus on a single purpose-such as water supply, water quality, endangered species protection, or flood management.

Even with mostly local management of water in the basin, the federal government still plays a prominent role, primarily as a builder, operator, financier, and regulator of water systems. The federal government has listed several species of fish as endangered or threatened-delta smelt, Chinook salmon, steelhead-which affects operations of the federal and state water export projects, the Central Valley Project (CVP) and State Water Project (SWP), respectively.

At the state level, the State Water Resources Control Board (SWRCB) and its local Central Valley Regional Water Quality Control Board oversee waste discharges to and water quality of the Sacramento River and its tributaries. The State Water Board also sets and enforces water quality standards in the San Francisco Estuary downstream, affecting CVP and SWP operations. The California Department of Water Resources (DWR) owns and operates the SWP's Oroville Dam-impounding the $4.2 \mathrm{~km}^{3}$ Oroville Reservoir on the Feather River, the largest tributary of the Sacramento River-and also has flood management responsibilities on the Sacramento Valley floor. In addition, the SWRCB administers a complex water rights system — another legacy of the Gold Rush—in part imported from the Mediterranean (Spain), in part inherited from wet-climate England [23].

\subsubsection{Water Infrastructure}

The cost of controlling or rearranging the Sacramento [River], which is to say the 'reclamation' of the Sacramento Valley, was largely borne, like the cost of controlling or rearranging many other inconvenient features of California life, by the federal government.

-Joan Didion

Notwithstanding the primary role of local government in water management, the major water supply scheme in the region is the federal CVP, composed of 20 dams, over $1100 \mathrm{~km}$ of conveyances, and 29 pumping and/or generating facilities [24]. It is anchored by Shasta Dam and Reservoir on the mainstem of the Sacramento River, built originally to repel the sea (and its salinity) from the delta. Water from the North Coast of California is actually diverted into the Sacramento River at the CVP's Keswick Dam (downstream of Shasta), via the Trinity River Diversion. The other major water project in the Sacramento River watershed is the aforementioned SWP. Both the SWP and CVP use the Sacramento River as its main conveyance for water that is exported from their pumping stations in the southern Sacramento-San Joaquin Delta, for transport throughout California.

The watershed's steep mountainous topography contributes to its high flood risk. There are approximately 200,000 people exposed to flood hazard in the 100 -year floodplain $(8 \%$ of the total population of the region), with $\$$ US 16.7 billion value of exposed infrastructure-including 135 essential facilities-and over \$US 1 billion in exposed agricultural crops [23]. Flood management and its infrastructure is a mix of federal, state, and local responsibility. For instance, at the state level, the "State Plan of Flood Control" includes $1600 \mathrm{~km}$ of levees in the Sacramento Valley, and a series of weir-and-bypass systems which in some ways reconnect the river to its historic floodplain [23].

\subsubsection{Climate Change Impacts}

In the Sacramento River region, it is expected that the increasing temperature trends of the last century will continue and even accelerate in this century [49]. During the 20th century, the region experienced increases in mean temperature from 0.4 to $1.3^{\circ} \mathrm{C}$ [50]. By the mid-21st century, projections are for an increase in annual mean temperatures in the range of 2.2 to $2.6^{\circ} \mathrm{C}$ [50]. As for precipitation, projections are highly uncertain, even with respect to whether the climate will become wetter or dryer. Northern California is already experiencing a transition to more rain and less snow that is expected to continue [50]. Precipitation may only slightly change in the early 21st century, with a potential increase in the northern Sacramento Valley and the Sierra Nevadas towards the end of the century [24]. 
Changes in temperatures and precipitation patterns will in turn change runoff. Moreover, extreme events may change in frequency, magnitude, and duration [50]. Continued warming is expected to elevate the snowline, causing snowpack to decline precipitously, especially at lower elevations such as the northern Sierra Nevadas, reducing natural water storage [50]. Late fall and winter runoff will likely increase, intensifying winter flooding, while spring and early summer runoff will decrease [50]. In fact, peak runoff due to the spring snowmelt on the Sacramento River has already shifted forward by nearly an entire month [50]. In general, extreme water flows can erode riverbanks, degrade riparian habitat, and mobilize sediment and bedload, impairing water quality and interfering with fisheries [5]. Ironically, climate change may restore some portion of the peak flows that were reduced by dam building.

Increases in temperature will also lead to increased evapotranspiration, affecting both urban and agricultural water demand [23]. River temperatures may increase because of less cold water available from behind dams [24]. Water-based recreational opportunities may be reduced, due to reduced reservoir levels [24]. Interestingly, with greater reservoir releases in the spring to maintain river flows and in the fall for delta outflow, storage availability may increase for flood management entering the winter [24]. Of particular concern, current water management infrastructure was designed using the observed hydrology of the first half of the 20th century, a record that is receding in its relevance [43].

Like temperatures, sea levels are expected to continue rising in the lower part of the basin, in the Sacramento-San Joaquin River Delta. During the 20th century, sea levels at the Golden Gate (where San Francisco Bay meets the Pacific Ocean) rose $18 \mathrm{~cm}$; another 12-61 cm of rise is expected by 2050 [51]. Complicating the relative certainty of sea level rise at the Golden Gate is the uncertainty of how that rise will be propagated through San Francisco Bay, upstream into the delta, and into the lower reaches of the Sacramento River. Salinity is also expected to increase due to sea level rise, which may reduce water exports and habitat for delta smelt [24]. While increased salinity places delta smelt at further risk, reduced water exports from the delta due to sea level rise could result in improved upstream passage of spawning salmon - though, as noted, adult salmon migration may be adversely affected by the reduced availability of cold water from reservoirs upstream, as well as by changing ocean conditions [24].

Of all impacts examined, Reclamation [24] highlighted two for their potential consequences. First, earlier runoff will fill reservoirs earlier in the season; when combined with existing "flood rule curves" (which statutorily and inflexibly set reservoir operating levels based upon historical hydrology), earlier releases from surface storage would be required in order to reserve reservoir space for flood management. Second, sea level rise will result in increased salinity in the delta, affecting the drinking water quality of exported water and aquatic habitat. When combined with tidal and storm surge, sea level rise could also lead to levee failures and even further seawater and salinity intrusion into the lower reaches of the Sacramento River.

\subsubsection{Adaptation Strategies}

The framework for adapting to climate change in the Sacramento River basin is similar to adaptation strategies employed elsewhere in California. It includes a mix of "traditional" approaches (e.g., dams, water conservation) and "non-traditional" approaches, such as integrated regional water management (IRWM), integrated flood management, and sustainable groundwater management [49]. Strategies to address climate change may, of course, address other stressors of water management, such as population increases and lifestyle changes. Here we highlight five major efforts that are underway to improve water management and adapt to climate change in the Sacramento basin.

As noted earlier, water governance is highly decentralized in California. Further, climate change impacts will not be the same across the state; each region will experience a different set and amount of impacts [50]. Thus, with respect to both institutions and impacts, adaptation must allow for regionally customized responses. The state's primary tool in this regard is IRWM, which is a voluntary planning framework, in which a broad range of stakeholders collaborate to use their local data, knowledge, and 
expertise to develop consensus-based regional water management plans. These plans are composed of a diversified portfolio of water management strategies, which go beyond traditional infrastructure-based solutions. That said, these plans have so far primarily focused on water supply; nonetheless, they can and do include strategies for water quality, environmental restoration, groundwater management, and flood control [52]. Currently, the state recognizes 48 regional water management groups, eight of which are in the Sacramento River Hydrologic Region [23]. The regional plans can also be submitted to the state for match funding; in the Sacramento River Hydrologic Region, over \$US 268 million from state and non-state sources has been expended on IRWM-related projects as of 2013 [23]. Indeed, the merging of climate change and IRWM planning represents a transformation in the way California approaches water management [53].

Not voluntary is the 2009 water conservation law (Senate Bill x7-7) [54], part of an overall package of institutional reforms enacted following California's 2007-2009 drought. Senate Bill x7-7 requires a permanent $20 \%$ reduction in urban per capita water use by the year 2020 . But even this statewide mandate allows for local tailoring, in part due to different climate conditions across the state. For purposes of implementing this law, the average, baseline per capita water use in the Sacramento River Hydrologic Region was established at 1030 liters per day [23]; further, the mandate also extends to the cities to which Sacramento River water is exported. While the per capita reduction obviously applies only to municipal water use, Senate Bill x7-7 also requires agricultural water suppliers to develop and implement agricultural water management plans, and update these plans every five years. In addition, agricultural water suppliers must measure the quantity of water delivered to customers, implement a pricing structure based in part on those measurements, and adopt efficient irrigation practices.

Another state mandate with regional customization is the Sustainable Groundwater Management Act (SGMA) [55], passed in response to the current drought. SGMA empowers local agencies to sustainably manage their groundwater basins, with the backstop of state regulation. The act requires the prioritization of basins statewide, the collection of groundwater data, the formation of local groundwater sustainability agencies, and the development of local groundwater sustainability plans, which are to be implemented within 20 years. As noted earlier, for the Sacramento River Hydrologic Region, groundwater is an important resource, and can provide for conjunctive use opportunities (i.e., the coordinated management of surface water and groundwater), as well as a buffer or strategic reserve for climate change impacts.

The State's Central Valley Flood Protection Plan [56] has proposed the expenditure of \$US 14-17 billion over 20-25 years to comprehensively and significantly reduce flood risk, including in the Sacramento Valley. The plan involves structural and non-structural projects and actions, including building new and expanding existing flood bypasses, informing and coordinating operations with runoff forecasts, increasing flood storage in reservoirs, removing sediment from flood structures and basins, and improving levees. Along with the plan (due to be updated in 2017), a complementary Central Valley Flood System Conservation Strategy is also in development that addresses riverine and floodplain ecosystem functions. The Conservation Strategy's goals include: (1) improving hydrologic and geomorphic processes; (2) increasing the quantity, diversity, and connectivity of riverine and floodplain habitat; (3) enhancing the recovery and sustainability of specific, at-risk native species, as well as general biodiversity; and (4) reducing stressors of at-risk, native species [57]. As the best flood strategy may indeed be to "give the river room" [2], the Conservation Strategy specifically highlights the need to reduce constraints on channel migration and provide for a sufficiently broad river corridor [57].

DWR is investigating the construction of new offstream storage-Sites Reservoir-in the Sacramento Valley near the community of Maxwell [58]. The proposed reservoir would provide water for a variety of users, and a multitude of other benefits such as hydropower, recreation, flood protection, anadromous fisheries, and water quality (including salinity control downstream in the Sacramento-San Joaquin River Delta); climate change resilience is one of the specific project benefits. 
Its size would be between 1.6 and $2.2 \mathrm{~km}^{3}$, and its location off the mainstem of the Sacramento River would greatly minimize the traditional environmental impacts of dam construction discussed earlier. Even this state-initiated project may eventually become a local project, constructed and operated by a regional joint powers authority, though it would still support the statewide system of water exports from the Sacramento basin. In addition, the federal government is studying more surface storage in the region, specifically by increasing the height of Shasta Dam up to $5.6 \mathrm{~m}$, which would impound up to an additional $0.76 \mathrm{~km}^{3}$ of water [24]. Like the proposed Sites Reservoir, the expanded Shasta Reservoir would have multiple benefits beyond water supply. Native American communities, though, have raised concerns about raising Shasta Dam, including the potential of the expanded reservoir to inundate sites of cultural and historical importance [23]. With respect to salmon survival, both facilities would be better able to provide cold water, which will be even more important in a changing climate [45].

In its recent study, Reclamation examined a wide range of water management strategies to address climate change impacts. They included water use efficiency, surface and groundwater storage (including conjunctive use and groundwater recharge), and improved delta conveyance, as well as changes to water flow regimes to reflect the natural hydrography and, alternatively, to repel salinity from the delta. In general, water management actions that were effective in addressing future climate change impacts were those that addressed water delivery, such as increasing water supplies, improving water use efficiencies, and delta conveyance, with the latter specifically contributing to increased surface and groundwater storage and improved adult salmon migration [24].

\section{Discussion and Conclusions}

While certainly at different scales, the water resources of the Durance and the Sacramento basins are indeed similar in many ways (Table 2). Although the Durance is about one-fifth the size of the Sacramento-in terms of catchment area, annual flow, and water use-the two watersheds share comparable topographies and climates, including a wide range of precipitation spatially and temporally, leading to a high variability in flow regimes. In particular, the natural flow patterns in both basins are highly influenced by snowmelt.

Table 2. The Durance and Sacramento Rivers share a Mediterranean climate and other characteristics, yet differ in other respects.

\begin{tabular}{ccc}
\hline Parameter & Durance Basin & Sacramento River \\
\hline Watershed area $\left(\mathrm{km}^{2}\right)$ & 14,342 & 71,432 \\
River length $(\mathrm{km})$ & 321 & 719 \\
Highest river elevation $(\mathrm{m})$ & 4102 & 1120 \\
Mean annual precipitation $(\mathrm{cm})$ & 104 & 96 \\
Mean annual discharge $\left(\mathrm{km}^{3}\right)$ & 5 & 27 \\
Range of flow $\left(\mathrm{m}^{3} / \mathrm{s}\right)$ & $25-5200^{1}$ & $28-18,406^{2}$ \\
Population $($ millions $)$ & $0.5\left(2.7^{3}\right)$ & 3.3 \\
Total reservoir capacity $\left(\mathrm{km}^{3}\right)$ & 2.3 & 19 \\
Total water use $\left(\mathrm{km}^{3}\right)$ & 1.9 & 800,000
\end{tabular}

Notes: 1 [59]; ${ }^{2}$ Includes flow in the mainstem Sacramento River and the Yolo Bypass; ${ }^{3}$ Total population supplied by the Durance and Verdon Valley for domestic uses.

The hydrology of both basins has been extensively modified by dams and diversions. The Sacramento basin contains the largest reservoir in California, and the Durance the largest in metropolitan France (and second largest in all of Europe). Both watersheds experience an intense competition for water amongst different users. Hydroelectric development is the primary water user in the Durance, whereas irrigation is the largest demand in the Sacramento. Both rivers provide water supply outside of their catchments for both irrigation and domestic water users. One difference is that 
the Durance basin experiences two peak demand periods: one in the winter for hydroelectricity and then another in the summer for irrigation. Another difference is the heavy reliance on groundwater in the Sacramento basin. The history of water resources management in the Durance basin is obviously far longer than in the Sacramento.

The two basins are also similar in terms of climate change impacts. While precipitation projections are greatly dispersed for both regions, it is nonetheless expected that both the Durance and Sacramento will experience a decrease in snowpack and earlier snowmelt, resulting in reduced flows in the spring, and even lower flows in the summer, during the peak irrigation and domestic demand period. Of shared concern is that both basins may experience low flow events worse than those in the observed record, increasing the risk of water shortages. Hydropower and water-based recreation may also be adversely affected in both regions. Differences include future flood severity (no significant change in the Durance basin) and the effect of greater uncertainty introduced by climate change on different water-using sectors (e.g., in the Durance, only irrigation is thus affected).

Specific to the Durance basin, under global change scenarios, results suggest a decrease in water resources, an increase in pressure on water resources, and an increase in risk of period with restriction for basins that are not supplied by the three large reservoirs. Significant trends emerge on the summer low flows from all the research projects, and this finding should support the extension and the continuation of "no-regret" adaptation actions (e.g., water savings) already committed and the wish to open the debate on a new future balance between the water uses.

Implementing adaptation strategies in France is a major challenge to policy-making at both the national and local scale. There is a consciousness of local climate variability issues. However, barriers to developing effective adaptation strategies which are supported by the water users do persist. These obstacles are due to the wide range of sources of uncertainty in the projections, the difficulties for the stakeholders to project their activities into the future, and the perception of adaptation measures as additional (financial) constraints. Nonetheless, the Durance River basin is a breeding ground to develop adaptation measures: (i) hydraulic structures with large storage capacity do exist within the basin; (ii) the effects of climate change only exacerbate the increasing deficits due to human activities; (iii) the preventive actions in the year 2015 have demonstrated that stakeholders can act jointly to mitigate the negative impact of a major drought and to limit the water shortage [60]; and (iv) the Durance and Verdon Valley displays a long history of multi-purpose management, which allows for optimism about the ability of the water users to identify possible concerted and effective ways towards new rules for water sharing.

In the Sacramento River watershed, notwithstanding the great uncertainty in projections, climate change will likely continue the transition of precipitation to more rain than snow, reduce snowpack, and shift peak runoff to earlier in the winter. Changes in precipitation and runoff patterns may result in more intense, longer, and more frequent floods and droughts. Salinity increases due to sea level rise will affect water quality and habitat in the lower, tidal reaches of the river. At-risk fish species may become even more vulnerable in a changing climate.

Adaptation to climate change in the Durance and Sacramento watersheds share many similarities. The Sacramento basin-much like the Durance-benefits from existing, multi-purpose water management infrastructure, and the experience of muddling through the recent five-year drought together. The French have both national and river basin adaptation plans, while in California, regional water management (for surface water, groundwater, and flood waters) is the preferred scale of action, notwithstanding state planning and projects and federal involvement in the background. Indeed, responding to climate change impacts-given their complexity, inherent uncertainty, and interaction with other water management stressors-call for a basin-scale approach that involves local stakeholders. In the Durance basin, for instance, involvement of stakeholders is particularly important, as socio-economic factors harbor the most uncertainty for the future. In addition, water conservation-both in the Durance and Sacramento catchments themselves, as well as in their export areas-is a common strategy for furthering water supply, with California mandating a $20 \%$ 
reduction in urban per capita water use by 2020, and in France, a $20 \%$ reduction in water abstractions by the 2020s.

Moreover, adaptation responses in southern France and northern California depend upon whether current water management rules remain inflexible or are themselves adaptable to a changing climate. In the Durance, for instance, such flexibility may be critical to avoid reductions in hydropower during the peak energy demand period. In California, water legislation and policy has recently shown substantial flexibility, for example, in the form of integrated regional water management (IRWM), a statewide water conservation mandate, and emerging regional flood and groundwater management efforts. Of course, implementation of all of these initiatives remains challenging, to say the least. Our analysis suggests that institutional improvements-for example, being more coordinated and efficient with data to inform and modify current water management capabilities and rules-may be as important as constructing new infrastructure in adapting to the changing Mediterranean-climate in both of these basins.

Acknowledgments: John T. Andrew is the Assistant Deputy Director of the California Department of Water Resources, which in part provided his time to participate in this study. The French national research project $\mathrm{R}^{2} \mathrm{D}^{2}-2050$ was coordinated by Sauquet and supported in part by the GICC program of the French Ministry for Ecology and the Rhone-Mediterranean and Corsica Water Agency. Eric Sauquet thanks all the participants from the partner institutions involved in the $R^{2} D^{2}-2050$ project that contributed to the results presented in this article.

Author Contributions: John T. Andrew served as lead and corresponding author. Eric Sauquet wrote the Durance basin portion of this article, and Andrew wrote the Sacramento River portion. Both authors contributed to the Introduction, Materials and Methods, Discussion and Conclusions.

Conflicts of Interest: The authors declare no conflicts of interest.

\section{Abbreviations}

The following abbreviations are used in this manuscript:

$\begin{array}{ll}\text { CLSM } & \text { Catchment Land Surface Model } \\ \text { CVP } & \text { Central Valley Project } \\ \text { DCR } & \text { crisis flow ("Débit de Crise" in French) } \\ \text { DWR } & \text { Department of Water Resources } \\ \text { CEQUEAU } & \text { Centre Québecois de l'EAU } \\ \text { EDF } & \text { Électricité de France } \\ \text { GCM } & \text { General Circulation Model } \\ \text { GICC } & \text { Management and Impacts of Climate Change ("Gestion et Impacts du Changement Climatique" } \\ \text { GR5J } & \text { in French) } \\ \text { IRWM } & \text { modèle du Génie Rural à 5 paramètres Journalier } \\ \text { km } & \text { Integrated Regional Water Management } \\ \text { kWh } & \text { kilometer } \\ \text { m.a.s.l. } & \text { kilowatt-hour } \\ \text { MW } & \text { meters above sea level } \\ \text { PET } & \text { megawatt } \\ \text { PNACC } & \text { potential evapotranspiration } \\ \text { R } 2 \text { D'-2050 } & \text { French National Climate Change Adaptation Plan (Plan National d'Adaptation au Changement } \\ \text { RBMP } & \text { Climatique in French) } \\ \text { RMC } & \text { Risk, water Resources and sustainable Development within the Durance River basin in 2050 } \\ \text { SGMA } & \text { River Basin Management Plans (Schéma Directeur d'Aménagement et de Gestion des Eaux } \\ \text { SWP } & \text { in French) } \\ \text { SWRCB } & \text { Rhone, Mediterranean and Corsica } \\ \text { TWA } & \text { State Water Project } \\ \text { \$US } & \text { State Water Resources Control Board } \\ & \text { total water abstraction } \\ & \text { United States Dollars }\end{array}$




\section{References}

1. Bonada, N.; Resh, V.H. Mediterranean-climate streams and rivers: Geographically separated but ecologically comparable freshwater systems. Hydrobiologia 2013, 719, 1-29. [CrossRef]

2. Kondolf, G.M.; Podolak, K.; Grantham, T.E. Restoring Mediterranean-climate rivers. Hydrobiologia 2013, 719, 527-545. [CrossRef]

3. Filipe, A.F.; Lawrence, J.E.; Bonada, N. Vulnerability of stream biota to climate change in Mediterranean climate regions: A synthesis of ecological responses and conservation challenges. Hydrobiologia 2013, 719, 331-351. [CrossRef]

4. Stella, J.C.; Rodriquez-Gonzales, P.M.; Dufour, S.; Bendix, J. Riparian vegetation research in Mediterranean-climate regions: Common patterns, ecological processes, and considerations for management. Hydrobiologia 2013, 719, 291-315. [CrossRef]

5. Palmer, M.A.; Lettenmaier, D.P.; Poff, N.L.; Postel, S.L.; Richter, B.; Warner, R. Climate change and river ecosystems: Protection and adaptation options. Environ. Manag. 2009, 44, 1053-1068. [CrossRef] [PubMed]

6. Grantham, T.E.; Figueroa, R.; Prat, N. Water management in Mediterranean river basins: A comparison of management frameworks, physical impacts, and ecological responses. Hydrobiologia 2013, 719, 451-482. [CrossRef]

7. Kondolf, G.M.; Piégay, H. Why Compare the Rhône and Sacramento Rivers? In Proceedings of the Rhône-Sacramento River Management Workshop, Institute for International Studies, Berkeley, CA, USA, 15 December 2014.

8. Stella, J.C.; Piégay, H.; Gruel, C.; Riddle, J.; Raepple, B. Riparian Forest Impacts and Dynamics on Large Rivers Managed for Multiple Uses; Insights from the Sacramento (California USA) and Rhône (France). In Proceedings of the IsRivers 2015, Second International Conference on Integrative Sciences and Sustainable Development of Rivers, Lyon, France, 22-26 June 2015; p. 244.

9. Comby, E.; Le Lay, Y.; Piégay, H. From Risk Management to Integrated Risk Management? Comparing the Rhône River with the Sacramento River. In Proceedings of the IsRivers 2015, Second International Conference on Integrative Sciences and Sustainable Development of Rivers, Lyon, France, 22-26 June 2015; p. 224.

10. Pinto, P.; Kondolf, G.M. Evolution of two urbanized estuaries: Environmental change, legal framework, and implications for sea-level rise vulnerability. Water 2016, 8, 535. [CrossRef]

11. Serra-Llobet, A.; Conrad, E.; Schaefer, K. Governing for integrated water and flood risk management: Comparing approaches in spain and california. Water 2016, 8, 445. [CrossRef]

12. Chauveau, M.; Chazot, S.; Perrin, C.; Bourgin, P.-Y.; Sauquet, E.; Vidal, J.-P.; Rouchy, N.; Martin, E.; David, J.; Norotte, T.; et al. What will be the impacts of climate change on surface hydrology in France by 2070 ? La Houille Blanche 2013, 4, 1-15.

13. Habets, F.; Boé, J.; Déqué, M.; Ducharne, A.; Gascoin, S.; Hachour, A.; Martin, E.; Pagé, C.; Sauquet, E.; Terray, L.; et al. Impact of climate change on the hydrogeology of two basins in Northern France. Clim. Chang. 2013, 121, 771-785. [CrossRef]

14. Hendrickx, F.; Sauquet, E. Impact of warming climate on water management for the Ariège river basin (France). Hydrol. Sci. J. 2013, 58, 976-993. [CrossRef]

15. Sauquet, E.; Arama, Y.; Blanc-Coutagne, E.; Bouscasse, H.; Branger, F.; Braud, I.; Brun, J.-F.; Chérel, Y.; Cipriani, T.; Datry, T.; et al. Water allocation and uses in the Durance River basin in the 2050s: Towards new management rules for the main reservoirs? La Houille Blanche 2016, 5, 1-6.

16. Thirel, G.; Andréassian, V.; Perrin, C.; Audouy, J.-N.; Berthet, L.; Edwards, P.J.; Folton, N.; Furusho, C.; Kuentz, A.; Lerat, J.; et al. Hydrology under change. An evaluation protocol to investigate how hydrological models deal with changing catchments. Hydrol. Sci. J. 2015, 60, 1184-1199. [CrossRef]

17. Magand, C.; Ducharne, A.; Le Moine, N.; Brigode, P. Parameter transferability under changing climate: case study with a land surface model in the Durance watershed, France. Hydrol. Sci. J. 2015, 60, 1408-1423. [CrossRef]

18. Vidal, J.-P.; Hingray, B.; Magand, C.; Sauquet, E.; Ducharne, A. Hierarchy of climate and hydrological uncertainties in transient low-flow projections. Hydrol. Earth Syst. Sci. 2016, 20, 3651-3672. [CrossRef] 
19. Magand, C.; Ducharne, A.; Le Moine, N.; Gascoin, S. Introducing hysteresis in snow depletion curves to improve the water budget of a land surface model in an Alpine catchment. J. Hydrometeorol. 2014, 15, 631-649. [CrossRef]

20. Pushpalatha, R.; Perrin, C.; Le Moine, N.; Mathevet, T.; Andréassian, V. A downward structural sensitivity analysis of hydrological models to improve low-flow simulation. J. Hydrol. 2011, 411, 66-76. [CrossRef]

21. Krause, P. Quantifying the impact of land use changes on the water balance of large catchments using the J2000 model. Phys. Chem. Earth 2002, 27, 663-673. [CrossRef]

22. Van der Linden, P.; Mitchell, J.F.B. ENSEMBLES: Climate Change and Its Impacts: Summary of Research and Results from the ENSEMBLES Project; Met Office, Hadley Centre: Exeter, UK, 2009.

23. California Climate Change Assessments. Available online: http://www.climatechange.ca.gov/climate_ action_team/reports/climateassessments.html (accessed on 18 August 2016).

24. California Department of Water Resources. California Water Plan Update 2013 (Bulletin 160-13); California Department of Water Resources: Sacramento, CA, USA, 2014.

25. U.S. Bureau of Reclamation. Sacramento and San Joaquin Basins Study, Report to Congress; U.S. Department of the Interior: Washington, DC, USA, 2015.

26. Gasith, A.; Resh, V. Streams in Mediterranean climate regions: Abiotic influences and biotic responses to predictable seasonal events. Annu. Rev. Ecol. Syst. 1999, 30, 51-81. [CrossRef]

27. Ball, J.E.; Bêche, L.A.; Mendez, P.K.; Resh, V.H. Biodiversity in Mediterranean-climate streams of California. In Hydrobiologia; 2013; Volume 719, pp. 187-213.

28. Grantham, T.E.; Merenlender, A.M.; Resh, V.H. Climatic influences and anthropogenic stressors: An integrated framework for streamflow management in Mediterranean-climate California, USA. Freshw. Biol. 2010, 55 (Suppl. 1), 188-204. [CrossRef]

29. Kondolf, G.M.; Batalla, R.J. Hydrological effects of dams and water diversions on rivers of Mediterranean-climate regions: Examples from California. In Catchments Dynamics and River Processes: Mediterranean and Other Climate Regions; Garcia, C., Batalla, R.J., Eds.; Elsevier B.V.: Amsterdam, The Netherlands, 2005; pp. 197-212.

30. Sauquet, E.; Gottschalk, L.; Krasovskaïa, I. Estimating mean monthly runoff at ungauged locations: An application to France. Hydrol. Res. 2008, 39, 403-423. [CrossRef]

31. Propluvia. Available online: http:/ / propluvia.developpement-durable.gouv.fr (accessed on 10 October 2016).

32. Cipriani, T.; Tilmant, F.; Branger, F.; Sauquet, E.; Datry, T. Impact of climate change on aquatic ecosystems along the Asse river network. In Hydrology in a Changing World: Environmental and Human Dimensions; Daniell, T., Ed.; AIHS Publication 363; IAHS Press: Wallingford, UK, 2014; pp. 463-468.

33. Snover, A.K.; Hamlet, A.F.; Lettenmaier, D.P. Climate-change scenarios for water planning studies. Bull. Am. Meteorol. Soc. 2003, 84, 1513-1518. [CrossRef]

34. Datry, T. Benthic and hyporheic invertebrate assemblages along a flow intermittence gradient: Effects of duration of dry events. Freshw. Biol. 2012, 57, 563-574. [CrossRef]

35. Samie, R.; Bouscasse, H.; Arama, Y.; Sauquet, E.; Brun, J.-F.; Strosser, P.; Roux, D. Anticipating and quantifying scenarios for future water management planning of the Durance-Verdon chain. Sci. Eaux Territ. 2017, 22, 42-47.

36. Green, M.; Weatherhead, E.K. The application of probabilistic climate change projections: A comparison of methods of handling uncertainty applied to UK irrigation reservoir design. J. Water Clim. Chang. 2014, 5, 652-666. [CrossRef]

37. Hazen, A. Storage to be provided in impounding reservoirs for municipal water supply. Trans. Am. Soc. Civ. Eng. 1914, 77, 1539-1640.

38. Vogel, R.M.; Bolognese, R.A. Storage-reliability-resilience-yield relations for over-year water supply systems. Water Resour. Res. 1995, 31, 645-654. [CrossRef]

39. Adaptation au Changement Climatique. Available online: http://www.eaurmc.fr/climat.html (accessed on 10 October 2016).

40. Wright, S.A.; Schoelhamer, D.H. Trends in sediment yield of the Sacramento River, California, 1957-2001. San Franc. Estuary Watershed Sci. 2004, 2, 1-14.

41. Sacramento River Basin. Available online: http://www.sacriver.org/aboutwatershed/roadmap/ sacramento-river-basin (accessed on 19 August 2016). 
42. Walker, P.R. Rivers to the Pacific. In Exploring the Great Rivers of North America; Melham, T., Ed.; National Geographic Society: Washington, DC, USA, 1999; pp. 126-139.

43. Jones, J. California, a State of Extremes: Management Framework for Present-Day and Future Hydroclimate Extremes. In Water Policy and Planning in a Variable and Changing Climate; Miller, K.A., Hamlet, A.F., Kenney, D.S., Redmond, K.T., Eds.; CRC Press: Danvers, MA, USA, 2016; pp. 207-222.

44. Hall, W.H. Report of the State Engineer to the Legislature of California, Session of 1880, Part 3: The Flow of the Mining Detritus; State Office: Sacramento, CA, USA, 1880.

45. Yates, D.; Galbraith, H.; Purkey, D.; Huber-Lee, A.; Sieber, J.; West, J.; Herrod-Julius, S.; Joyce, B. Climate warming, water storage, and Chinook salmon in California's Sacramento Valley. Clim. Chang. 2008, 91, 335-350.

46. Thompson, L.C.; Escobar, M.I.; Mosser, C.M.; Purkey, D.R.; Yates, D.; Moyle, P.B. Water management adaptations to prevent loss of spring-run chinook salmon in California under climate change. J. Water Resour. Plan. Manag. 2012, 138, 465-478. [CrossRef]

47. Didion, J. Where I Was From; Alfred A. Knopf: New York, NY, USA, 2003.

48. Kelly, R. Battling the Inland Sea: Floods, Public Policy, and the Sacramento Valley; University of California Press: Berkeley, CA, USA, 1989.

49. California Natural Resources Agency. Safeguarding California Plan; California Natural Resources Agency: Sacramento, CA, USA, 2014.

50. California Department of Water Resources. California Climate Science and Data for Water Resources Management; California Department of Water Resources: Sacramento, CA, USA, 2015.

51. National Research Council. Sea-Level Rise for the Coasts of California, Oregon, and Washington: Past, Present, and Future; The National Academies Press: Washington, DC, USA, 2012.

52. Conrad, E. Climate Change and Integrated Regional Water Management in California: A Preliminary Assessment of Regional Approaches; Department of Environmental Science, Policy and Management, University of California at Berkeley: Berkeley, CA, USA, 2012.

53. Spanos, K.A. Water management: From an uncertain present to a sustainable future. Gold. Gate Univ. Environ. Law J. 2014, 7, 143-191.

54. The Water Conservation Act of 2009. Available online: http://www.water.ca.gov/wateruseefficiency/sb7/ (accessed on 22 June 2016).

55. Water Education Foundation. The 2014 Sustainable Groundwater Management Act: A Handbook to Understanding and Implementing the Law; Water Education Foundation: Sacramento, CA, USA, 2015.

56. California Department of Water Resources. Central Valley Flood Protection Plan; California Department of Water Resources: Sacramento, CA, USA, 2012.

57. California Department of Water Resources. Central Valley Flood System Conservation Strategy (Draft); California Department of Water Resources: Sacramento, CA, USA, 2015.

58. California Department of Water Resources. North-of-the-Delta Offstream Storage: Investigation Highlights; California Department of Water Resources: Sacramento, CA, USA, 2014.

59. Pardé, M. Quelques Nouveautés sur le Régime du Rhône; Institut des Etudes Rhodanienne de l'Université de Lyon, Géocarrefour: Lyon, France, 2004; p. 139.

60. EDF Délégation de bassin Rhône Méditerranée (EDF). Gestion Estivale de l'Eau-Bassin Rhône Méditerranée; EDF: Lyon, France, 2016; p. 15.

(C) 2017 by the authors; licensee MDPI, Basel, Switzerland. This article is an open access article distributed under the terms and conditions of the Creative Commons Attribution (CC BY) license (http:/ / creativecommons.org/licenses/by/4.0/). 